\title{
Antiamnesic evaluation of $C$. phlomidis Linn. bark extract in mice
}

\author{
Hanumanthachar Joshi ${ }^{*}$, Krupa Megeri ${ }^{2}$ \\ ${ }^{1}$ SET's College of Pharmacy, ${ }^{2}$ Department of Biotechnology, Karnataka University
}

Clerodendron phlomidis Linn. (Verbenaceae) is known as
Agnimantha in sanskrit. Bark of the plant is used in treating various
nervous disorders. In the present study C. phlomidis was
investigated for its potential as a nootropic agent in mice. The
aqueous extract of the C. phlomidis (100 and $200 \mathrm{mg} / \mathrm{kg}$, p.o.) was
administered for 6 successive days to both young and aged mice.
Exteroceptive behavioral models such as elevated plus maze and
passive avoidance paradigm were employed to evaluate short term
and long term memory respectively. Scopolamine (0.4 mg/kg, i.p.),
diazepam (1 mg/kg, i.p.) were employed to induce amnesia in mice.
To delineate the mechanism by which C. phlomidis exerts nootropic
action, its effect on brain acetyl cholinesterase levels were
determined. Piracetam (200 mg/kg, i.p.) was used as a standard
nootropic agent. Pretreatment with C. phlomidis (100 and 200 mg/
kg, p.o.) for 6 successive days significantly improved learning and
memory in mice. It reversed the amnesia induced by scopolamine,
diazepam and natural ageing. It also decreased the acetyl
cholinesterase levels in the whole brain. The bark of C. phlomidis
can be of enormous use in the management of treatment of cognitive
disorders such as amnesia and Alzheimer's disease.

\section{INTRODUCTION}

Neurodegenerative diseases are now generally considered as a group of disorders that seriously and progressively impair the functions of the nervous system through selective neuronal vulnerability of specific brain regions. Alzheimer's disease (AD) is the most common neurodegenerative disease (Scatena et al., 2007), which affects the brain and hence memory. It is a chronic, progressive organic brain disorder characterized by disturbance of multiple cortical functions, including memory, judgement, orientation, comprehension, learning capacity and language (Jay, 2005). Clinically, the disorder is characterized by a gradual but progressive decline in memory and other cognitive domains and the frequent occurrence of noncognitive behavioral symptoms. Neuropathologically, the cardinal features of AD include neuritic plaques, neuro-fibrillary tangles, and the loss of synapses and neurons (Caselli et al., 2006). AD has been identified as a protein misfolding disease due to the accumulation of abnormally folded amyloid beta protein in the brains of AD patients (Hashimoto et al., 2003). Amyloid beta $\left(\mathrm{A}^{2}\right)$, is a short peptide that is an abnormal proteolytic byproduct of the transmembrane protein amyloid precursor protein (APP), whose function is unclear but thought to be involved in neuronal development (Kerr, Small, 2005). Neuropathogenesis is proposed to be a result of the accumulation of amyloid beta peptides in the brain together with oxidative stress mechanisms and neuroinflammation 
(Newman et al., 2006). AD begins as a deficiency in the production of the neurotransmitter acetylcholine. Patients with $\mathrm{AD}$ show loss of cognitive, intellectual,functional and social abilities, and therefore become fully dependent on their caregiver. It is estimated that in 2010 over five million people will be diagnosed with probable AD in the United States alone. Increasing age is the greatest risk factor for $\mathrm{AD}$; one-tenth of elderly over 65 years of age develop $\mathrm{AD}$, whereas nearly half of those over age 85 are diagnosed with probable AD. Certain people in the population are at greater risk of developing $\mathrm{AD}$ due to various genetic risk factors associated with $A D$ such as apolipoprotein (APO) polymorphism (Francesco et al., 2006). A person with $\mathrm{AD}$ is expected to live an average of 8 years and up to 20 years after the onset of symptoms. An association between cholesterol and the development of $A D$ was suggested in the early 1990s and ever since, an increasing amount of research has confirmed that there is a link between cholesterol and the development of AD. A high cholesterol levels in midlife is a risk for AD (Sjogren et al., 2006). The National Institute of Health predicts, if the current trend continues, there will be more than 8.5 million AD patients by the year 2030 in USA alone (Anonymous, 2000). Although there is no cure for dementia of AD type at present, alternative pharmacologic treatment modalities can reduce the symptoms of cognitive impairment and slow disease progression (Geldmacher, 2003). Nootropic agents like, piracetam and cholinesterase inhibitors like, Donepezil ${ }^{\circledR}$ are commonly used for improving memory, mood and behavior. However, the resulting adverse effects of these drugs such as diarrhea, insomnia, nausea, bronchitis, loose stools, muscular cramps and other known side effects (Doody et al., 2001), has made their use limited and it is worthwhile to explore the utility of traditional medicines in the treatment of various cognitive disorders. In the early stages of this neurodegenerative process it is more pronounced in cholinergic-type brain centres. One of the most notable of these is the amount of attention recently being paid to the enzyme AChE, which increases the bioavailability of the neurotransmitter in the cholinergic synapses by preventing the hydrolysis of acetylcholine (Gandia et al., 2006). Herbal medicines can be used in the treatment of AD (Izzo, Capasso, 2007). Higher intake of folate and vitamins B6 (pyridoxine hydrochloride) and B12 (cyanocobalamin) may decrease the risk of $\mathrm{AD}$ through the lowering of homocysteine levels (Luchsinger et al., 2007).

Clerodendron phlomidis Linn. (verbenaceae) is known as Agnimantha in Sanskrit. Bark of the plant is used for treating various nervous disorders (Chopra, 1956). A decoction of $C$. phlomidis leaves is used along with other parts for inflammation and is effective in treating bronchitis, headache, weakness, drowsiness and digestive problems (Nadkarni, 1976). C. phlomidis has also shown antidiarrhoeal activity (Rani et al., 1999) and antifungal activity (Rajasekaran et al., 2006). A new chalcone glycoside, together with pectolinarigenin, 7-hydroxyflavone and 7-hydroxyflavanone 7-O-glucoside have been isolated from the flowers and leaves of $C$. phlomidis (Roy, Pandey, 1994).

In the present study $C$. phlomidis was investigated for its potential as a nootropic agent. Elevated plus maze and passive avoidance paradigms were the exteroceptive behavioral models to assess short-term and long term memory respectively. To delineate the mechanism by which C. phlomidis exerts nootropic action, its effects on brain cholinesterase levels were also determined.

\section{MATERIALS AND METHODS}

\section{The plant material}

The bark of Clerodendron phlomidis (Family Verbenaceae) was obtained from Dharwad, Karnataka, India. The plant was authenticated and identified by Dr. S. Hebbar, taxonomist, Department of Botany, Karnatak University, Dharwad. The specimen has been kept at Dept. of Pharmacognosy, SET'S college of Pharmacy, Dharwad, Karnataka, India.

\section{Preparation of extract}

The bark was dried in shade; cleaned, powdered and aqueous extract was prepared by simple maceration process using $1000 \mathrm{~g}$ of powder. The extract was concentrated using rotary flash evaporator followed by freeze drying. The yield of the dry extract from crude powder of $C$. phlomidis was $2 \%$. A suspension was prepared using tween 80 and administered orally.

\section{Drugs and chemicals}

Scopolamine hydro bromide (Sigma Aldrich, USA), diazepam (Valium ${ }^{\circledR}$, Ranbaxy laboratories Ltd., Mumbai, India), piracetam (Nootropil ${ }^{\circledR}$ UCB India pvt. Ltd., Vapi, India) and phenytoin (Zydus Neurosciences, Ahmedabad, India) were diluted in normal saline and injected intraperitoneally (i.p.). Volume of injection was $1 \mathrm{ml} / 100 \mathrm{~g}$ body weight of the mouse.

\section{Animals}

Swiss mice of either sex weighing around $18 \mathrm{~g}$ (younger, 8 weeks old) and $25 \mathrm{~g}$ (older, 28 weeks old) were used in the present study. Animals were procured from 
disease free animal house, BLDEA Medical College, Bijapur. They were acclimatized to the laboratory conditions for 5 days before behavioral studies. The animals had free access to food and water and maintained under 12:12 h light and dark cycles. All experiments were carried out during day time from 900 to 1900 hours. The Institutional Animals Ethics Committee (IAEC) approved the experimental protocol and care of animals was taken as per guidelines of CPCSEA, Dept. of Animal Welfare, Govt. of India ( $\left.{ }^{\circ} .412\right)$.

\section{MEMORY MODELS}

\section{Exteroceptive behavioral model}

\section{Elevated plus maze}

The elevated plus maze served as the exteroceptive behavioral model (where in stimulus existed outside the body) to evaluate learning and memory in mice (Joshi, Parle, 2006). The apparatus consists of two open arms (16 $\mathrm{cm} \times 5 \mathrm{~cm})$ and two covered arms $(16 \mathrm{~cm} \times 5 \mathrm{~cm} \times 12 \mathrm{~cm})$. The arms extended from a central platform $(5 \mathrm{~cm} \times 5 \mathrm{~cm})$, and maze is elevated to a height of $25 \mathrm{~cm}$ from the floor. On the first day, each mouse was placed at the end of open arm, facing away from the central platform. Transfer latency (TL) was taken as the time taken by mouse to move into one of the covered arm with all its four legs. TL was recorded on the first day. If the animal did not enter into one of the covered arms within $90 \mathrm{sec}$, it is gently pushed into one of the two covered arms and the TL was assigned as 90 seconds. The mouse was allowed to explore the maze for 10 seconds and then returned to its home cage. Memory retention was examined on the second day, 24 hours after the first day's trial (Dhingra et al., 2004; Itoh et al., 1990; Parle, Dhingra, 2003; Joshi et al., 2006).

\section{Passive shock avoidance paradigm}

Passive avoidance behavior based on negative reinforcement was used to examine the long term memory. The apparatus consisted of a box $(27 \times 27 \times 27 \mathrm{~cm})$ having three walls of wood and one wall of Plexiglas, featuring a grid floor ( $3 \mathrm{~mm}$ stainless steel rods set $8 \mathrm{~mm}$ apart), with a wooden platform $(10 \times 7 \times 1.7 \mathrm{~cm})$ in the center of the grid floor. The box was illuminated with a $15 \mathrm{~W}$ bulb during the experimental period. Electric shock (20V AC) was delivered to the grid floor. Training was carried out in two similar sessions. Each mouse was gently placed on the wooden platform set in the center of the grid floor. When the mouse stepped down and placed on the wooden platform set in the center of the grid floor. When the mouse stepped down and placed all its paws on the grid floor, shocks wee delivered for $15 \mathrm{sec}$ and the step-down latency (SDL) was recorded. SDL was defined as the time taken by the mouse to step down from wooden platform to grid floor with its entire paw on the grid floor. Animals showing SDL in the range $(2-15 \mathrm{sec})$ during the first test were used for the second session and the retention test. The second-session was carried out $90 \mathrm{~min}$ after the first test. When the animals stepped down before $60 \mathrm{sec}$, electric shocks were delivered for $15 \mathrm{sec}$. During the second test, animals were removed from shock free zone if they did not step down for a period of $60 \mathrm{sec}$. Retention was tested after $24 \mathrm{~h}$ in a similar manner, except that the electric shocks were not applied to the grid floor. Each mouse was again placed on the platform, and the SDL was recorded, with an upper cut-off time of 300 s (Joshi, Parle, 2005; Parle et al., 2004; Joshi, Parle, 2006a).

\section{Interoceptive behavioral models:}

Scopolamine induced amnesia - Amnesia was induced by administration of scopolamine hydrobromide on $6^{\text {th }}$ day and the TL recorded. Retention was recorded after $24 \mathrm{hr}$. CP (100 and $200 \mathrm{mg} / \mathrm{kg})$ and piracetam $(200 \mathrm{mg} / \mathrm{kg})$ were administered for 6 days successively. On $7^{\text {th }}$ day, after $45 \mathrm{~min}$ of administration of doses, scopolamine $(0.4 \mathrm{mg} / \mathrm{kg}$, p.o.) was administered and TL and SDL noted after $45 \mathrm{~min}$.

Diazepam induced amnesia - Diazepam $(1 \mathrm{mg} / \mathrm{kg}$, i.p.) was administered to young mice and TL was noted after 45 min of injection on $6^{\text {th }}$ day and after $24 \mathrm{hr}$. CP (100 and $200 \mathrm{mg} / \mathrm{kg}$, p.o. $)$ and piracetam $(200 \mathrm{mg} / \mathrm{kg}$, ip $)$ were administered for 6 successive days. After $60 \mathrm{~min}$ of administration of the last dose on $6^{\text {th }}$ day, diazepam was administered. TL and SDL were noted after $45 \mathrm{~min}$ of administration of diazepam and after $24 \mathrm{hr}$ (Joshi, Parle, 2006 b).

\section{Estimation of brain Acetyl cholinesterase (AChE) activity}

On the $7^{\text {th }}$ day the animals were euthanized by cervical dislocation carefully to avoid any injuries to the tissue. The whole brain AChE activity was measured using the Ellman method (Ellman et al., 1961). The end point was the formation of yellow color due to the reaction of thiocholine with dithiobisnitrobenzoate ions. The rate of formation of thiocholine from acetylcholine iodide in the presence of tissue cholinesterase was measured using a spectrophotometer. The sample was first treated with 5, 5'-dithionitrobenzoic acid (DTNB) and the optical density (OD) of the yellow color compound formed during the reaction at $412 \mathrm{~nm}$ every minute for a period of three minutes was measured. Protein estimation was done using Folin's method. AChE activity was calculated using the following formula: 
$\mathrm{R}=\frac{\mathrm{d} \text { O.D. } \mathrm{x} \text { volume of assay }(3 \mathrm{ml})}{\mathrm{Ex} \mathrm{mg} \text { of protein }}$

Where $\mathrm{R}=$ Rate of enzyme activity in ' $\mathrm{n}$ ' mole of acetylcholine iodide hydrolyzed / minute / $\mathrm{mg}$ protein. $\mathrm{d}$ O.D. $=$ Change in absorbance $/ \mathrm{min}$ and $\mathrm{E}=$ Extinction coefficient $=13600 / \mathrm{M} / \mathrm{cm}$.

\section{Statistical Analysis}

All the results were expressed as mean \pm Standard error. The data was analyzed using ANOVA followed by Tukey- kramer test. $\mathrm{P}<0.01$ was considered as statistically significant.

\section{RESULTS}

\section{Acute toxicity studies}

C. phlomidis aqueous extract at different doses (50$1000 \mathrm{mg} / \mathrm{kg}$ ) was administered orally to the mice with the help of a specially designed oral needle connected to a polythene tube. Mice, which received extracts in doses above $1000 \mathrm{mg} / \mathrm{kg}$, exhibited ptosis (dropping of upper eyelids) and were found lethargic. The parameters such as hyperactivity, grooming, convulsions, sedation, hypothermia and mortality were observed. The doses selected were $100 \mathrm{mg} / \mathrm{kg}$ and $200 \mathrm{mg} / \mathrm{kg} /$ day.

\section{Effect on transfer latency $(\mathrm{TL})$ using elevated plus maze}

Aged mice showed higher transfer latency (TL) values on first day and on second day (after $24 \mathrm{hr}$ ) as compared to young mice, indicating impairment in learning and memory. Piracetam (200 mg/kg, i.p.) pretreatment for 6 days decreased TL on $6^{\text {th }}$ day and after $24 \mathrm{hrs}$ i.e. on $7^{\text {th }}$ day as compared to control, indicating improvement in both learning and memory (Figure 1). Scopolamine $(0.4 \mathrm{mg} / \mathrm{kg})$ and Diazepam $(1 \mathrm{mg} / \mathrm{kg})$ increased TL significantly $(\mathrm{P}<$ 0.05 ) in young mice on first day and second day as compared to control, indicating impairment of memory (Figure 2).

C. phlomidis (100 and $200 \mathrm{mg} / \mathrm{kg}$, p.o.) decreased the TL on $6^{\text {th }}$ day and $7^{\text {th }}$ day in young and aged mice $(\mathrm{P}<0.05)$ when compared to control groups. Higher doses of CP $(200 \mathrm{mg} / \mathrm{kg}$, p.o.) more significantly enhanced the learning and memory of aged animals rather than the young mice as reflected by marked decrease in TL on $6^{\text {th }}$ and $7^{\text {th }}$ day when subjected to elevated plus maze tests. The higher doses of CP pretreatment for 6 days successively to young mice protected them against scopolamine, diazepam and ageing induced amnesia.

\section{Effect on SDL using Passive avoidance apparatus}

C. phlomidis extract (200 mg/kg, p.o.) profoundly increased SDL as compared to control group on second day

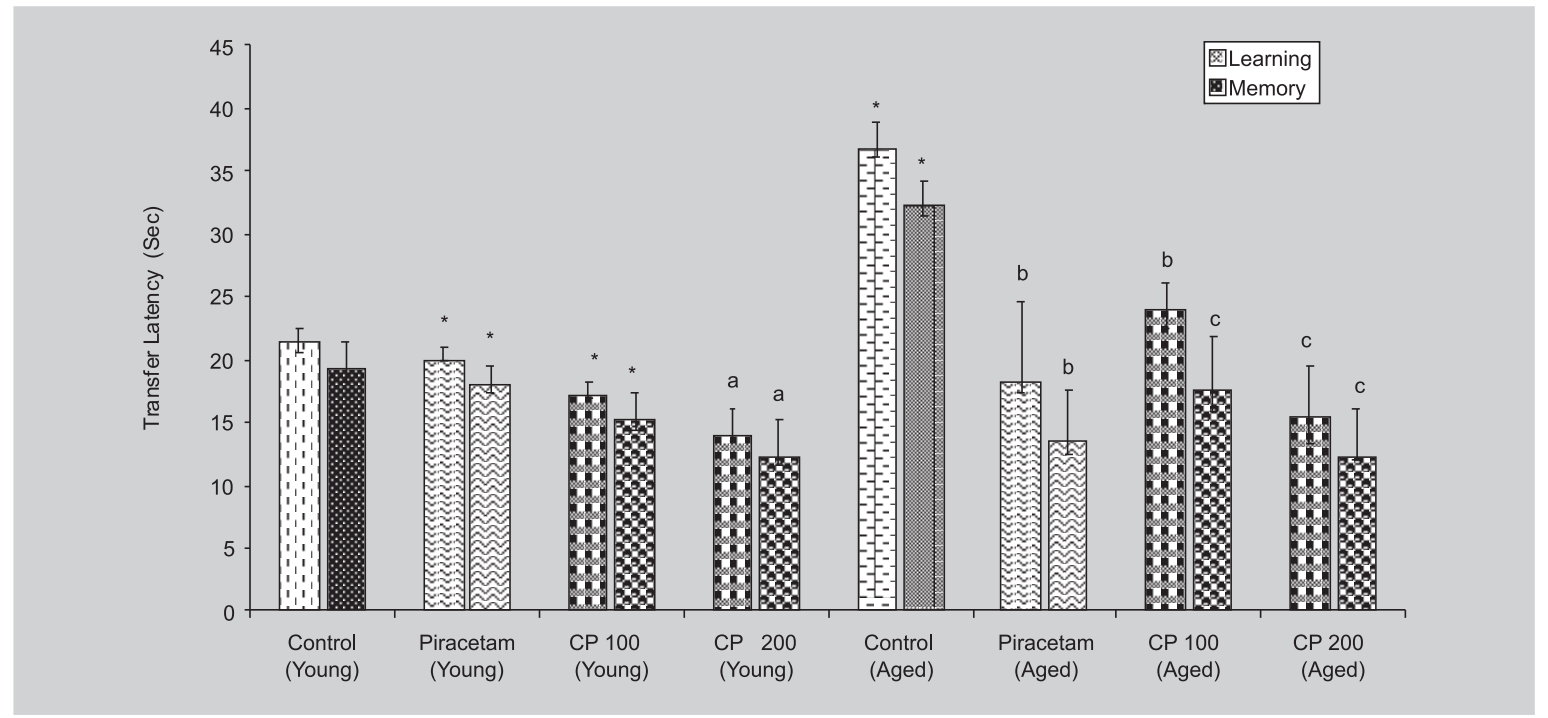

FIGURE 1 - Effect of C. phlomidis (CP) on transfer latencies of young and aged mice.

\footnotetext{
All values are mean \pm SEM : ANOVA followed by Tukey- Kramer test

* denotes $\mathrm{P}<0.01$ as compared to control (Young)

a denotes $\mathrm{P}<0.001$ as compared to control (Young)

$\mathrm{b}$ denotes $\mathrm{P}<0.01$ as compared to control (Aged)

c denotes $\mathrm{P}<0.001$ as compared to control (Aged)
} 


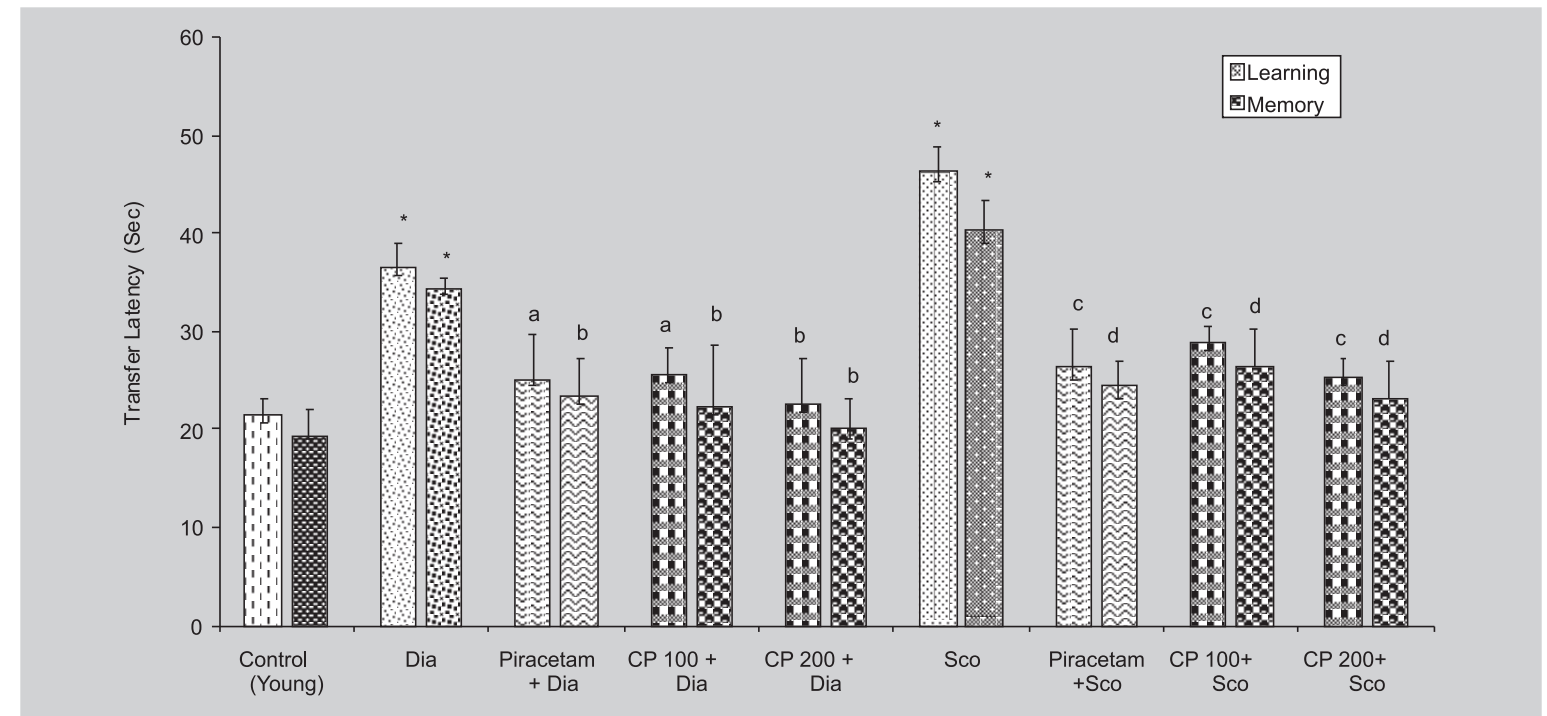

FIGURE 2 - Effect of C. phlomidis (CP) on transfer latencies of diazepam and scopolamine induced mice.

\footnotetext{
All values are mean \pm SEM : ANOVA followed by Tukey- Kramer test

* denotes $\mathrm{P}<0.01$ as compared to control (Young)

a denotes $\mathrm{P}<0.01$ as compared to diazepam treated mice

$\mathrm{b}$ denotes $\mathrm{P}<0.001$ as compared to diazepam treated mice

c denotes $\mathrm{P}<0.01$ as compared to scopolamine treated mice

d denotes $\mathrm{P}<0.001$ as compared to scopolamine treated mice
}

indicating improvement in the memory of young mice. Furthermore, this dose of $C$. phlomidis reversed diazepam and scopolamine significantly decreased SDL on second day indicating impairment of memory (Figure 3 ).

\section{Effect on whole brain acetylcholinesterase (AChE) activity}

The whole brain AChE activity with phenytoin (12 $\mathrm{mg} / \mathrm{kg}$, p.o.) exhibited significant elevation to $\mathrm{AChE}$ activity as compared to control and piracetam $(200 \mathrm{mg} / \mathrm{kg}$, p.o.). C. phlomidis (200 mg/kg, p.o.) significantly reduced AChE activity (Figure 4).

\section{DISCUSSION}

Alzheimer's disease (AD) is a progressive disease of the brain. It is a common type of dementia in the elderly, which can have devastating outcomes on the diagnosed patient, on the caregiver and family, and on society at large. $\mathrm{AD}$ is a major cause of disability and mortality, and its impact on health care costs, including direct and indirect medical and social service costs, is estimated to be greater than $\$ 100$ billion per year. AD typically presents with an insidious decline in memory that progresses to affect language, visuospatial perception, calculations, and executive functioning. Behavioral and psychiatric symptoms are also frequent in $\mathrm{AD}$ (Yaari, Corey-Bloom, 2007). The treatment of AD is a clinical challenge (Gustavo et al., 2006). Many other conditions can lead to similar memory loss, confusion, agitation and metabolic disturbances (Francesco et al., 2006). The symptoms of dementia are oxidative damage, impaired neurotransmission and degeneration of neuronal circuits in the affected brain areas (Joshi, Parle, 2006a). Oxidative damage accompanies $\mathrm{AD}$, and cholinesterase inhibitors are recommended for use in mild to moderate AD (Joshi, Parle, 2006b). In exteroceptive behavioral models, the stimulus lies outside the body where as, it lies within the body in case of interoceptive behavioral models. Passive avoidance behavior is a classic paradigm to assess memory with strong aversive component (Poirier, 2002), based on negative reinforcement and is used in the present study to examine long-term memory where as Elevated plus maze was used to examine short term memory (Doody et al., 2001). Interoceptive behavioral models such as scopolamine and natural aging induced amnesia are widely cited as models simulating human dementia in general and AD in particular (Cahil et al., 1998). Modulation of brain aging with complex extracts containing active phytochemicals has been useful in the aging of wild type rodents with encouraging results (Giacobini, 1998). 


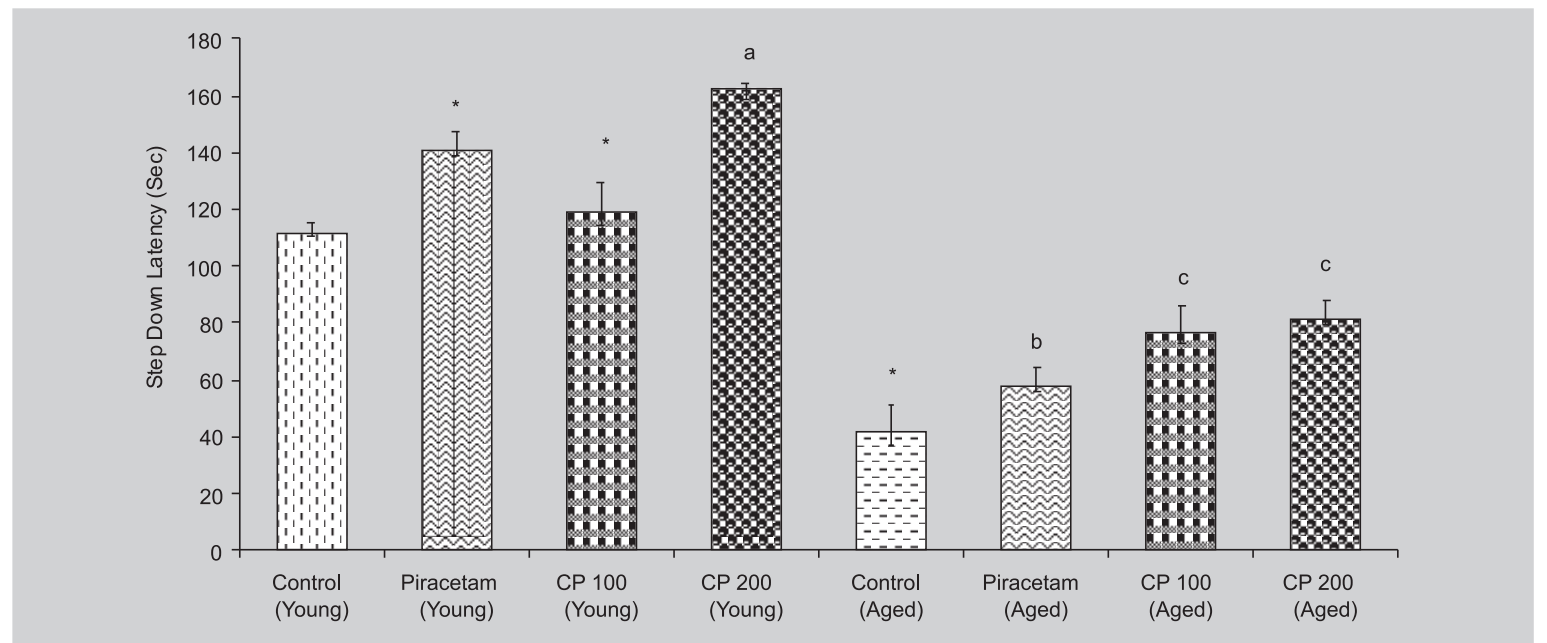

FIGURE 3 - Effect of C. phlomidis (CP) on step down latency of young and aged mice.

All values are mean \pm SEM : ANOVA followed by Tukey- Kramer test

* denotes $\mathrm{P}<0.01$ as compared to control (Young)

a denotes $\mathrm{P}<0.001$ as compared to control (Young)

$\mathrm{b}$ denotes $\mathrm{P}<0.01$ as compared to control (Aged)

c denotes $\mathrm{P}<0.001$ as compared to control (Aged)

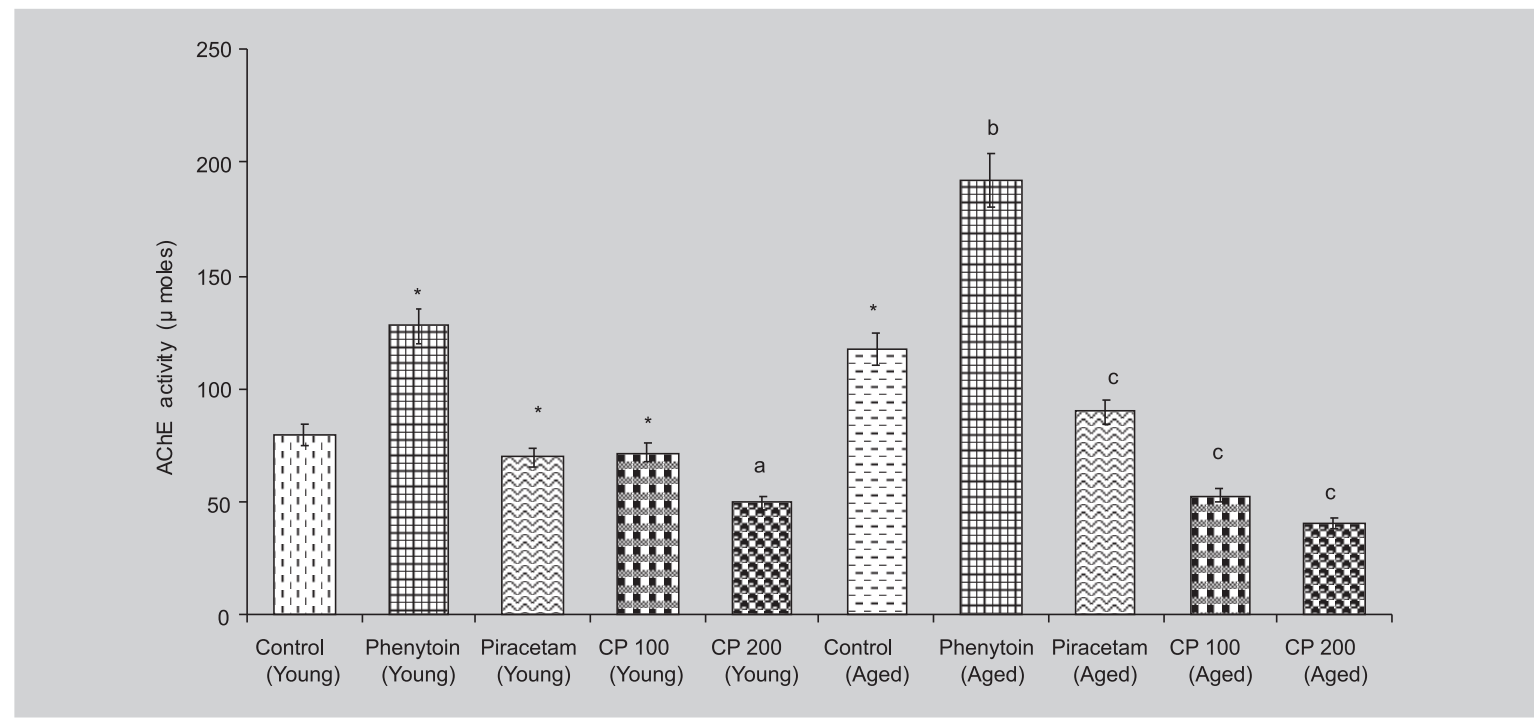

FIGURE 4 - Effect of C. phlomidis (CP) on acetylcholinesterase activity of young and aged mice.

All values are mean \pm SEM : ANOVA followed by Tukey- Kramer test

* denotes $\mathrm{P}<0.01$ as compared to control (Young)

a denotes $\mathrm{P}<0.001$ as compared to control (Young)

$\mathrm{b}$ denotes $\mathrm{P}<0.01$ as compared to control (Aged)

c denotes $\mathrm{P}<0.001$ as compared to control (Aged)

Neurodegenerative disorders, such as AD, are often characterised by the degeneration of the cholinergic system. Thus, the aim of many treatment regimens is to support this system either by means of muscarinic agonists or by inhibitors of acetylcholinesterase (AChE), the latter being able to increase the concentration of acetylcholine
(Holzgrabe et al., 2007).

The present study indicates that $C$. phlomidis is a potential anti-cholinesterase agent. It also possesses nootropic activity in view of its facilitatory effect on retention of acquired learning. Cognitive deterioration occurring in patients with probably $\mathrm{AD}$ is associated with progressive loss 
of cholinergic neurons and consequent decline in levels of acetylcholine (Ach) in brain. Cholinergic deficits occur in the brain of patients with $\mathrm{AD}$ and vascular dementia (Mckeith et al., 2003; Tohgi et al., 1990;). Altered hippocampal neurogenesis may also play a pathophysiological role in neurodegenerative disorders such as $\mathrm{AD}$ (Elder et al., 2006). Phenytoin is known to reduce hippocampal $\mathrm{ACh}$ concentration and causes cognitive impairment (Sudha et al., 2001). The aqueous extract of $C$. phlomidis significantly inhibited the AChE activity in the whole brain homogenate of mice, indicating its potential in the attenuation of learning and memory deficits especially in aged mice. Considering the lack and need of drugs with proven effectiveness in improving learning and memory (Bhattacharya et al., 2000), the specific memory improving effects of $C$. phlomidis reported in the present study is of enormous interest and deserves further investigations using more experimental paradigms for further confirmation of memory improving potential of C. phlomidis in the treatment of various cognitive disorders.

\section{CONCLUSION}

Considering the lack and the need of the drugs with proven effectiveness in improving learning and memory, the specific memory improving, anticholinesterase and anticholesterol effects of C. phlomidis can be of enormous use in the management of preliminary symptoms of dementia and Alzheimer's disease.

\section{RESUMO}

\section{Avaliação da atividade antiamnésica da casca de $C$. phlomidis Linn. em camundongos}

Clerodendron phlomidis Linn. (Verbenaceae) é conhecida como Agnimantha em sânscrito. A casca da planta é utilizada no tratamento de várias disfunções neurológicas. No presente estudo, C. phlomidis foi investigada pelo seu potencial como agente nootrópico em camundongos. $O$ extrato aquoso de C. phlomidis (100 e $200 \mathrm{mg} / \mathrm{kg}$, p.o.) foi administrado por seis dias consecutivos tanto para camundongos jovens quanto para idosos. Modelos comportamentais exteroceptivos, tais como labirinto em cruz elevada e paradigma de esquiva passiva foram empregados para avaliar memória recente e tardia, respectivamente. Escopolamina (0,4 mg/kg i.p.), diazepam (1 $\mathrm{mg} / \mathrm{kg}$ i.p.) foram empregados para induzir amnésia em camundongos. A fim de delinear o mecanismo pelo qual C. phlomidis exerce ação nootrópica, determinaram-se seus efeitos nos niveis cerebrais de acetilcolinesterase.
Utilizau-se piracetam (200 mg/kg i.p.) como nootrópico padrão. O pré-tratamento com C. phlomidis 100 e 200 $\mathrm{mg} / \mathrm{kg}$, p.o.) por seis dias sucessivos melhorou, significativamente, o aprendizado e a memória em camundongos. Ela reverteu a amnésia induzida por escopolamina, diazepam e pelo envelhecimento normal. Também, diminuíram-se os níveis de acetilcolinesteraseem todo o cérebro. A casca de C. phlomidis pode ser de grande uso no tratamento de disfunções cognitivas, como amnésia e doença de Alzheimer.

UNITERMOS: Doença de Alzheimer. Agente nootrópico. Acetilcolinesterase. Clerodendron phlomidis.

\section{ACKNOWLEDGEMENT}

The authors express deep sense of gratitude to the management, SET's College of Pharmacy, Dharwad, Karnataka for providing the facilities. The authors are also thankful to Ranbaxy, India, for the generous supply of diazepam, UCB pvt. Ltd., India, for supply of piracetam and Zydus Neurosciences, India for the supply of phenytoin.

\section{REFERENCES}

NATIONAL INSTITUTE OF AGING-NATIONAL INSTITUTES OF HEALTH. Progress Report on Alzheimer's disease: Taking the next steps. Washington: National Institutes of Health, 2000. p.1154-1156.

BHATTACHARYA, S.K.; BHATTACHARYA, A.; KUMAR, A.; GHOSAL, S. Antioxidant activity of Bacopa monniera in rat frontal cortex, striatum and hippocampus. PTR, Phytother. Res., v.14, n.p.174-179, 2000.

CAHIL, L.; BRIONI, J.; IZQUIERDO, I. Mechanisms of emotional arousal and lasting declarative memory. Trends Neurosci., v.21, n. p.294-299, 1998.

CASELLI, R. J.; BEACH, T.J.; YAARI, R.; REIMAN, E, M. Alzheimer's disease-a century later. J. Clin. Psychiatry, v.67, n.11, p.1784-800, 2006.

CHOPRA, R.N. Glossary of Indian medicinal plants, CSIR, New Delhi, 1956, 162-164p.

DHINGRA, D.; MILIND, P.; KULKARNI, S.K. Memory enhancing activity of Glycyrrhiza glabra in mice. J. Ethnopharmacol., v. 1, n. p. 361-365, 2004. 
DOODY, R.S.; STEVENS, J.C.; BECK, R.N.; DUBINSKY, R.M.; KOYE, J.A.; GWYTHER, L. Practice parameters: Management of dementia (an evidence based review)report of the quality standards subcommittee of the American Academy of Neurology. Neurology, v.56, n. p. 1154-1166, 2001.

ELDER, G.A.; DE GASPERI, R.; GAMA SOSA, M. A. Research update: neurogenesis in adult brain and neuropsychiatric disorders. Mt. Sinai J. Med., v. 73, n.7, p. 731-740, 2006.

ELLMAN, G.L.; COURTNEY, K.D.; VALENTINO, A.J.; FEATHERSTONE, R.M. A new and rapid colourimetric determination of acetylcholinestrase activity. Biochem. Pharmacol., v.7, n. p. 88-95, 1961.

FRANCESCO, C.; AUDREY, M.N.; DAVID, R.M.; ERCOLANO, M.;PAOLO, P. Evidence based research in complementary and alternative medicine II: Treatment of patients with Alzheimer's disease. eCAM, v.3, n.4, p.411424, 2006.

GANDIA, L.; ALVAREZ, R.M.; HERNANDEZ-GUIJO, J.M.; GONZDEZ-RUBIO, J.M.; DE PASCULA, R.; ROJO, J.;TAPIA, L. Anticholinesterases in the treatment of Alzheimer's disease. Rev. Neurol., v. 27, n.1, p. 471477, 2006.

GELDMACHER, D.S. Alzheimer's disease: current pharmacotherapy in the context of patient and family needs. J. Am. Geriatr. Soc., v.51, n. p.89-95, 2003.

GIACOBINI, E. Invited review: Cholinesterase inhibitors for Alzheimer's disease therapy: from tacrine to future applications. Neurochem. Int., v.32, n.5-6, p.413-419, 1998.

HASHIMOTO, M.; ROCKENSTEIN, E.; CREWS, L.; MASLIAH, E. Role of protein aggregation in mitochondrial dysfunction and neurodegeneration in Alzheimer's and Parkinson's diseases. Neuromolecular. Med., v.4, n.1-2, p.21-36, 2003.

HOLZGRABE, U.; KAPKOVA, P.; ALPTUZUN, V.; SCHEIBER, J.; KUGELMANN, E. Targetting acetylcholinesterase to treat neurodegeneration. Expert Opin. Ther. Targets, v.11, n.2, p.161-179, 2007.
ITOH, J.; NABESHIMA, T.; KAMEYAMA, T. Utility of an elevated plus maze for the evaluation of nootropics, scopolamine and electro convulsive shock. Psychopharmacology, v.101, n. p.27-33, 1990.

IZZO, A.A.; CAPASSO, F. Herbal medicines to treat Alzheimer's disease. Trends Pharmacol. Sci., v. 28, n.2, p.47-48, 2007.

JOSHI, H.; PARLE, M. Antiamnesic effects of Desmodium gangeticum in mice. Yakugaku Zashshi, v. 126, n.2, p.1417,2006

JOSHI, H.; PARLE, M. Effects of piperine on memory and behavior mediated via monoamine neurotransmitters. $J$. Trad. Med., v. 2, n. p. 39-43, 2005a.

JOSHI, H.; PARLE, M. Evaluation of nootropic potential of Ocimum Sanctum Linn. in mice. Ind. J. Expt. Biol., v.44, n. p.133-136, 2006a.

JOSHI, H.; PARLE, M. Nardostachys jatamansi improves learning and memory in mice. J. Med. Food, v. 9, n.1, p. 113-118, 2006b

JOSHI, H.; PARLE, M. Evaluation of the antiamnesic effects of Phyllanthus niruri in mice. Colomb. Med., v.38, n.2,p. 132-139, 2007a.

JOSHI, H.; PARLE, M. Antiamnesic potentials of Foeniculum vulgare Linn. in mice. The Oriental Pharmacy and Experimental Medicine, v.7, n.2, p. 121129, 2007b.

JOSHI, H.; PARLE, M. Management of dementia through ayurvedic formulation brahmi rasayana BR-2T in mice. Alzheimers Dement., v.1, n.7, p. 64, 2005b.

JOSHI, H.; Soumya, S.V.; Chauhan, J. Pharmacological evidences for Anti-Alzheimer's potentials of Sesbania grandiflora in mice. Natural Products, v.3, n.3, p. 112$118,2007 \mathrm{c}$.

JAY, M.E. Cholinesterase inhibitors in the treatment of dementia. JAOA, v. 3, n. p. 145-158, 2005.

KERR. M.; SMALL, D. Cytoplasmic domain of the betaamyloid protein precursor of Alzheimer's disease: function, regulation of proteolysis, and implications for drug development. J. Neurosci. Res., v. 80, n.2, p. 151$159,2005$. 
LEOPALDO, L.S.; MARIA, A.V.T.; PATRICIA, M.; GUSTAVO, A.S. The use of herbal medicines in Alzheimer's disease- A systematic review. eCAM, v. 3, n.34, p. 441-445, 2006.

LUCHSINGER, J.A.; TANG, M.X.; MILLER, J.; GREEN, R.; MAYEUX, R. Relation of higher folate intake to lower risk of Alzheimer's disease in elderly. Arch Neurol., $v$. 64(1), p. 86-92, 2007.

MCKEITH, I.G.; BURNS, D.J.; BALLARD, C.G.; COLLERTON, D.; JARROS, E.; MORRIS, C.M. Dementia with lewy bodies. Semin. Clin. Neuropsychiatry, v.51, p. 296-304, 2003.

NADKARNI, A.K. Indian Materia Medica. Popular Prakashan.Bombay; 1976.

NEWMAN, M.; MUSGRAVE, F.I.; LARDELLI, M. Alzheimer's disease: Amyloidgenesis the presenilins and animal models. Biochem Biophys Acta, v.1772, p.285297, 2007.

PARLE, M.; DHINGRA, D. Ascorbic acid: a promising memory enhancer in mice. J. Pharmacol. Sci, v. 93, n. p. 129-135, 2003.

PARLE, M.; DHINGRA, D.; KULKARNI, S.K. Improvement of mouse memory by Myristica fragrans seeds. J. Med. Food, v. 7, p. 157-161, 2004.

POIRIER, J. Evidence that the clinical effects of cholinesterase inhibitors are related to potency and targeting of action. Int. J. Clin. Pract. Suppl., v. 127, p. 619, 2002.

RAJASEKARAN, A; PONNUSAMY, K. Antifungal activity ofClerodendron. Inerme $(\mathrm{L})$ and Clerodendron. Phlomidis (L). Turk. J. Biol., v.30, n. p.139-142, 2006.
RANI, S.; AHAMED, N.; RAJARAM, S.; SALUJA, R.; THENMOZHI, S.; MURUGESAN, T. Anti-diarrhoeal evaluation of Clerodendrum phlomidis Linn.leaf extract in rats. J. Ethnopharmacol., v.68, n. p.315-319, 1999.

ROY, R.; PANDEY, V.B. Achalcone glycoside from Clerodendron phlomidis. Phytochemistry, v.37, n.6, p.1775-6, 1994.

SCATENA, R.; MARTORONA, G.E.; BOTTANI, P.; BOTTA, G.; PASTOVE, P.; GIARDINA, B. An update of pharmacological approaches to neurodegenerative diseases. Expert Opin. Investig. Drugs, v. 16, n.1, p.59$72,2007$.

SJOGREN, M.; MIELXE, M.; GUSTAFSON, D.; ZANDI, P.; SKOOG, I. Cholesterol and Alzheimer's disease - is there a relation. Mech. Ageing. Dev., v.127, n.2, p.138-47, 2006.

SUDHA, S.; MADEPALLI, K.; LAKSHMANA.; PRADHAN, N. Chronic phenytoin induced impairment of learning and memory with associated changes in brain acetyl cholinesterase activity and monoamine levels. Pharmacol. Biochem. Behav., v.52, n. p.119-124, 2001.

TOHGI, H.; ABE, T.; KIMURA, M.; SAHEKI, M.; TAKAHASHI, S. Cerebrospinal fluid acetylcholine and choline in vascular dementia of Binswanger and multiple small infarct types as compared with Alzheimer type dementia. J. Neural. Transm., v. 103, n. p. 1211-1220, 1990.

YAARI, R.; COREY-BLOOM, J. Alzheimer's disease. Semin. Neurol., v. 27, n.1, p. 32-41, 2007.

Recebido para publicação em 21 de janeiro de 2008 Aceito para publicação em 30 de julho de 2008 